Sains Malaysiana 50(8)(2021): 2207-2218

http://doi.org/10.17576/jsm-2021-5008-06

\title{
Effects of Different Drying Methods and Solvents on Biological Activities of Curcuma aeruginosa Leaves Extract
}

(Kesan Kaedah Pengeringan dan Pelarut Berbeza pada Aktiviti Biologi Ekstrak Daun Curcuma aeruginosa)

\author{
Wan NaJiYah Hanun Wan NaSir, Nurul NaJiha Ain Ibrahim, WoOn Kuo HaO, AZliana Abu BaKar \\ Sajak, Noor-Soffalina Sofian-Seng, Wan Aida Wan Mustapha \& HafeedZa Abdul Rahman*
}

\begin{abstract}
Curcuma aeruginosa Roxb. is one of the plants from the Zingiberaceae family which the rhizome has been used for medicinal purposes. However, the biological properties of the leaves have not been fully explored. Therefore, this study was conducted to evaluate the effects of different drying methods and solvents on total phenolic content, antioxidant and anti-hyperglycemic activities of $\mathrm{C}$. aeruginosa leaf extract. Samples were dried by oven drying $(O D)$ and freeze drying (FD), and then extracted using different ratios of ethanol:water (100:0, 50:50 and 0:100). The amount of phenolic content $(T P C)$ was determined using a spectrophotometer. Antioxidant activity was tested using the Free Radical Scavenging (DPPH) test and the Ferric Reducing Antioxidant Power assay (FRAP), while the anti-hyperglycemic test was evaluated by determining the percentage of $\alpha$-glucosidase inhibition. The results showed that FD at 100:0 and 50:50 concentrations had the highest phenolic content (30.88 and $33.06 \mathrm{mg} \mathrm{GAE} / \mathrm{g}$ extract, respectively) and highest antioxidant activity value (38.24 and $42.46 \mathrm{mg}$ TEAC/g extract, respectively). For DPPH, FD at 50:50 showed the highest inhibition of $71.48 \%$ compared to other extracts. Whereas FD at 100:0, 50:50 and 0:100 showed the highest $\alpha$-glucosidase inhibition of 25.65, 30.78 and $27.65 \%$, respectively. However, compared to Quercetin, the extract showed mild anti-hyperglycemic activity. The results indicated that FD is the best method of drying while 50:50 showed as the best solvents. Positive correlation between TPC with antioxidant and anti-hyperglycemic activities showed that C. aeruginosa leaf has potential as a source of natural antioxidant with the presence of phenolic compounds.
\end{abstract}

Keywords: Anti-hyperglycemic; antioxidant; freeze drying; oven drying; phenolic

ABSTRAK

Curcuma aeruginosa Roxb. merupakan tumbuhan daripada famili Zingiberaceae yang mana rizomnya telah digunakan secara tradisi untuk tujuan perubatan. Namun begitu, aktiviti biologi daripada bahagian daun masih belum diterokai secara meluas. Oleh itu, penyelidikan ini dijalankan untuk mengkaji kesan kaedah pengeringan dan penggunaan nisbah pelarut yang berbeza terhadap jumlah kandungan fenol, aktiviti antioksidan dan anti-hiperglisemik ekstrak daun C. aeruginosa. Pengeringan ketuhar $(P K)$ dan pengeringan sejuk beku $(P B)$ telah digunakan untuk mengeringkan daun dan kemudiannya diekstrak menggunakan etanol:air dengan nisbah berbeza (100:0, 50:50 dan 0:100). Spektrofotometer telah digunakan untuk menentukan jumlah kandungan fenol (TPC) pada ekstrak. Aktiviti antioksidan pula telah diuji dengan menggunakan ujian Pemerangkapan Radikal Bebas (DPPH) dan ujian Penurunan Ferik (FRAP), manakala ujian anti-hiperglisemik pula dinilai dengan menentukan peratusan perencatan $\alpha$-glukosidase. Hasil menunjukkan bahawa PB pada kepekatan 100:0 dan 50:50 mempunyai kandungan fenol tertinggi (masing-masing 30.88 dan $33.06 \mathrm{mg} \mathrm{GAE/g}$ ekstrak) dan nilai aktiviti antioksidan paling tinggi (masing-masing 38.24 dan $42.46 \mathrm{mg}$ TEAC/g ekstrak). Bagi DPPH, PB 50:50 menunjukkan peratusan perencatan tertinggi sebanyak $71.48 \%$ apabila dibandingkan dengan ekstrak lain. $P B$ pada 100:0, 50:50 dan 0:100 menunjukkan perencatan a-glukosidase tertinggi masing-masing sebanyak 25.65, 30.78 dan 27.65\%. Namun begitu, apabila dibandingkan dengan Kuersetin, ekstrak menunjukkan aktiviti anti-hiperglisemik yang rendah. Keputusan ini menunjukkan bahawa PB adalah kaedah pengeringan terbaik manakala pelarut 50:50 merupakan pelarut paling sesuai untuk pengekstrakan daun C. aeruginosa. Korelasi positif antara TPC dengan aktiviti antioksidan dan anti-hiperglisemik menunjukkan bahawa $\mathrm{C}$. aeruginosa mempunyai potensi sebagai sumber antioksidan semula jadi dengan kehadiran sebatian fenol.

Kata kunci: Anti-hiperglisemik; antioksidan; fenol; pengeringan beku; pengeringan ketuhar 


\section{INTRODUCTION}

Curcuma aeruginosa or also known as 'pink and blue ginger' in Malaysia, is among the herbs that is used traditionally to treat various diseases such as diarrhea, bloating, parasitic infections, and dengue fever (Choudhury et al. 2013; Moektiwardoyo et al. 2014). Studies on $C$. aeruginosa are gaining attention as extracts from this plant can also act as antioxidant, antibacterial, antiinflammatory, and antipyretic agents (Safitri et al. 2017; Simoh et al. 2018). Jarikasem et al. (2005) and Thaina et al. (2009) reported that there are sequential bioactive compounds in the rhizome extracts such as zedoalakton A, zedoalakton B, zedoarondiol, zedoarol, curcumenol, isocurcytol, furanodien, isofuranodien, curzerenone, 1.8-sineol, and $\beta$-pinen. According to Mathela and Joshi (2012), curzerenone acts as one of the antioxidant and anti-bacterial agents. This is supported by George and Britto (2015) who also stated that this plant is indeed a high source of antioxidants such as flavonoids, curcumin, alkaloids and polyphenols. While most research was done on the rhizome of the plants, the biological activities of the leaves is yet to be explored.

Antioxidants are compounds that prevent oxidative processes due to the production of free radicals that can damage cells. The potential for antioxidants as therapeutic agents for oxidative stress-related diseases has gained much attention. Furthermore, plants have high potential to be commercialised as they are readily-available and inexpensive (Simoh \& Zainal 2015). Bioactive substances that act as antioxidant agents are essential to prevent free radical damage, as these reactions can occur in either the human body or the food system (Kumar \& Pandey 2013). According to Asif (2015), free radical reactions or reactive oxygen species (ROS) can cause biomolecular damage, which is the cause of cell death in the human body.

Studies on the relationship of free radical reactions to human health have long been observed because free radicals are thought to be contributing to diseases such as asthma, cancer, cardiovascular, and even diabetes (Phaniendra et al. 2015; Pizzino et al. 2017). This is supported by various findings which showed that polyphenol compounds are able to protect cells from oxidative damage through various mechanisms, therefore, lowering the risk of disease resulting from such oxidative stress (Hussain et al. 2016). In addition, oxidative stress responsible in pathogenesis of diabetes by the disruption of enzymatic systems, causing reduction in vitamin $\mathrm{C}$ levels, lipid peroxidation as well as impaired glutathione metabolism (Asmat et al. 2016). Previous studies suggested that plants with high phenolic content have strong antioxidant properties (Anuduang et al. 2020; Ismail et al. 2018; Ling et al. 2020). This occurs when these phenolic compounds bind to free radical ions and thus, inhibit the formation of ROS (Panche et al. 2016). Therefore, natural substances such as plants that have the potential to reduce oxidative stress or have antioxidant properties are said to be able to treat diseases caused by ROS including diabetes and cancer.

Previous studies have shown that the amount of polyphenols and antioxidant activity in a plant depends on biological factors (genotype, organ, and growth rate) and the environment (temperature, water, and light levels) (Medini et al. 2014). However, the amount or antioxidant content that can be extracted from a plant also depends on the type and concentration of the solvent used during the extraction process. According to Dent et al. (2013), polyphenol compounds have a wide range of polarities ranging from low to high polarity. Therefore, to obtain the optimal amount of extracts, various types of solvents can be used based on the solubility of the polyphenols such as water, ethanol, methanol, acetone or any mixture of water and alcohol. Ethanol has been known as a good solvent for polyphenol extraction and it is safe for human consumption. Ethanol is reliable and can consistently produce potent extractions with minimal fuss.

In addition, the pre-extraction drying process also affects the amount of bioactive and phytochemical content of plants. This is because bioactive substances are usually degraded due to high temperatures, high oxygen content, and exposure to radiation (Nguyen et al. 2015). It is important to know the appropriate solvent concentration and drying method during the phenolic determination process in order to enhance or optimise the phenolic content of a substance. Therefore, the objective of this study was to determine the effect of drying method and solvents on phenolic content, antioxidant and antihyperglycemic activities of the $C$. aeruginosa leaf extract.

\section{MATERIALS AND METHODS}

MATERIALS

All chemicals used in this study are of analytical grade. The chemicals used were ethanol, aluminium chloride $\left(\mathrm{AlCl}_{3}\right)$ (Hamburg Chemicals, Germany), 2,2-diphosphate-2-prylhydrazyl (DPPH), Folin Ciocalteu reagent (Vetec, Brazil), sodium carbonate, $\mathrm{FeCl}_{3} \cdot 6 \mathrm{H}_{2} \mathrm{O}$, 2,4,6-tripiridyl-1,3,5-triazine (TPTZ), sodium acetate trihydrate $\left(\mathrm{CH}_{3} \mathrm{COONa} .3 \mathrm{H}_{2} \mathrm{O}\right)$, p-nitrophosphate- $\alpha-\mathrm{D}$ - 
glucopiranoside, Quercetin (Merck, Germany) and $\alpha$-glucosidase (Megazyme, Australia).

\section{PROXIMATE COMPOSITION}

Fresh sample materials were used for quantitative determination of proximate composition such as moisture content, total ash, protein, fat, fiber, and carbohydrate. These physicochemical studies were done according to standard procedure of the Association of Official Analytical Chemists (AOAC 2000); meanwhile the carbohydrate content was estimated by subtracting the moisture, ash, protein fat and fiber values from 100. All analyses were carried out in triplicate and results obtained were reported in percentages.

\section{SAMPLE PREPARATION}

C. aeruginosa leaves were obtained from the Seri Suboh Herbal Park located in Kuala Pilah, Negeri Sembilan, Malaysia and identified by botanists from the Herbarium, Universiti Kebangsaan Malaysia (Voucher specimen ID: 026/2020). The fresh leaf samples were cleaned and dried using a clean dry tissue and kept at $4{ }^{\circ} \mathrm{C}$ (TSB-Inverter, Toshiba, Malaysia). The drying methods used in this study were oven drying (Memmert UN55, Germany) and freeze drying (Alpha LD Plus, CHR 101521, Germany). For oven drying, the sample is placed in an oven at 40 ${ }^{\circ} \mathrm{C}$ until constant weight of the sample was achieved. For freeze-drying, the samples were kept in the refrigerator at $-20^{\circ} \mathrm{C}$ for $48 \mathrm{~h}$ and then dried using a freeze dryer before the constant weight of the sample was obtained. The dried samples were ground into powder (Waring Blender 7011S, America) and sieved using a $300 \mu \mathrm{m}$ siever (mesh size: No. 50) before being stored at $-20^{\circ} \mathrm{C}$ for analysis.

\section{SAMPLE EXTRACTION}

The dry powder of $C$. aeruginosa leaves was extracted using the method performed by Rahman et al. (2017) with slight modifications. Samples were extracted using ethanol:water as the solvent at 100:0, 50:50 and 0:100 ratios $(\mathrm{v} / \mathrm{v})$. The dried sample $(10 \mathrm{~g})$ was extracted with $150 \mathrm{~mL}$ of solvent and left for $24 \mathrm{~h}$ in an incubator shaker (Infors HT Ecoton 4103, Switzerland) and kept at 25 ${ }^{\circ} \mathrm{C}$. The extract was then filtered using a Whatman No. 1 filter paper and the process was repeated three times for $24 \mathrm{~h}$ at a time. Solvent evaporation was performed using a rotary evaporator (Laboratoria 4000 efficient, Heidolph, Germany) at $40{ }^{\circ} \mathrm{C}$. The product from the evaporation process was then frozen so that the solvent and water content are completely removed. The extract was weighed and the percentage of recovery calculated using the following formula and stored at $-20{ }^{\circ} \mathrm{C}$ before further analysis:

$$
\text { Recovery }(\%)=\frac{\text { Weight of extract }(\mathrm{g})}{\text { Weight of fresh leaves }(\mathrm{g})} \times 100
$$

TOTAL PHENOLIC CONTENT (TPC)

The total phenolic content of $C$. eruginosa extract was determined based on the method of Hashim et al. (2019) with some modifications. Gallic acid was used as a standard $(0-250 \mu \mathrm{g} / \mathrm{mL})$. Extracts of $100 \mu \mathrm{L}$ of $0.2 \mathrm{~N}$ Folin Ciocalteu reagent, $20 \mu \mathrm{L}$ of $C$. eruginos $a$ extract and $80 \mu \mathrm{L}$ of $7.5 \%$ sodium carbonate were added in 96 -well microplates and allowed to react at room temperature for $2 \mathrm{~h}$. Absorbance readings were obtained using the EpochTM Microplate Spectrophotometer, Biotech Instrument (USA) at $765 \mathrm{~nm}$ where complex blue was formed. The standard curve is plotted with gallic acid and phenolic content is expressed as gallic acid equivalents in $\mathrm{mg}$ per $\mathrm{g}$ extract (GAE/g extract). The calibration equation for GA was $\mathrm{y}=0.0062 \mathrm{x}+0.1039\left(\mathrm{R}^{2}=0.999\right)$ where $\mathrm{y}$ refers to absorbance and $\mathrm{x}$ represents GA concentrations $(\mathrm{mg} / \mathrm{mL})$.

\section{FREE RADICAL SCAVENGING TEST (DPPH)}

Determination of antioxidant activity was performed using the method of Sin et al. (2018) with some modifications. Ascorbic acid and butylated hydroxyanisole (BHA) are used as positive controls. A total of $40 \mu \mathrm{L}$ extract of different concentrations were mixed with $280 \mu \mathrm{L}$ of DPPH solution provided in methanol $(25 \mu \mathrm{g} / \mathrm{mL})$. All mixtures were prepared in microplates and allowed to react for $30 \mathrm{~min}$ at room temperature in a dark. Absorption was measured using EpochTM Microplate Spectrophotometer, Biotech Instrument (USA) at $517 \mathrm{~nm}$.

\section{FERRIC REDUCING ANTIOXIDANT POWER ASSAY TEST (FRAP)}

Determination of the ferric reducing antioxidant power assay test (FRAP) was performed using method by Mirghani et al. (2018) with some modifications. Ferric chloride hexahydrate $\left(\mathrm{FeCl}_{3} \cdot 6 \mathrm{H}_{2} \mathrm{O}\right)$ solution, $10 \mathrm{mM}$ 2,4,6-tripiridyl-s-triazine (TPTZ) solution in $40 \mathrm{mM} \mathrm{HCl}$ 
and acetate buffer solution $\left(\mathrm{CH}_{3} \mathrm{COONa}\right)$ were prepared separately. A total of $5.4058 \mathrm{~g}$ of $\mathrm{FeCl}_{3} \cdot 6 \mathrm{H}_{2} \mathrm{O}$ powder was mixed with distilled water until completely dissolved and transferred into a $100 \mathrm{~mL}$ volumetric flask to produce $20 \mathrm{mM} \mathrm{FeCl} \cdot 6 \mathrm{H}_{2} \mathrm{O}$. The $10 \mathrm{mM}$ TPTZ solution was prepared by mixing $0.3121 \mathrm{mg}$ of TPTZ powder with 40 $\mathrm{mM} \mathrm{HCl}$ and then diluted to $100 \mathrm{~mL}$ using the same $\mathrm{HCl}$. The solution of acetic acid buffer with a concentration of $0.3 \mathrm{M}$, pH 3.6 was prepared by mixing $0.31 \mathrm{~g}$ of sodium acetate trihydrate $\left(\mathrm{CH}_{3} \mathrm{COONa} .3 \mathrm{H}_{2} 0\right)$ and $1.6 \mathrm{~mL}$ of glacial acetic acid and then diluted to $100 \mathrm{~mL}$ with distilled water. Acetate buffer solution, $10 \mathrm{mM}$ TPTZ solution and $20 \mathrm{mM} \mathrm{FeCl}_{3} \cdot 6 \mathrm{H}_{2} \mathrm{O}$ solution at a volume ratio of 10:1:1 were mixed to produce fresh FRAP solution. Next, 1950 $\mu \mathrm{L}$ of fresh FRAP solution was mixed with $50 \mu \mathrm{L}$ of sample extract for analysis. After $30 \mathrm{~min}$, the absorption readings were taken at $593 \mathrm{~nm}$ wavelength using an EpochTM Microplate Spectrophotometer, Biotech Instrument (USA). The standard curve was plotted with Trolox $(0-250$ $\mu \mathrm{g} / \mathrm{mL}$ ) and the value of the ferric reducing power is expressed as trolox equivalents in $\mathrm{mg}$ per g extract (mg TEAC/g extract). The calibration equation for Trolox was $\mathrm{y}=0.0034 \mathrm{x}+0.1413\left(\mathrm{R}^{2}=0.9816\right)$ where $\mathrm{y}$ is absorbance and $\mathrm{x}$ is $\mathrm{mg} / \mathrm{mL}$ of Trolox.

\section{$\alpha$ - GLUCOSIDASE INHIBITORY ACTIVITY}

$\alpha$-glucosidase inhibition was performed according to the method of Zayapor et al. (2020) with some modifications. The substrate solution (10 mM p-nitrophosphate- $\alpha-D$ glucopiranoside) was prepared in $50 \mathrm{mM}$ phosphate buffer (pH 6.5). Then, $10 \mu \mathrm{L}$ of sample, $130 \mu \mathrm{L}$ of $30 \mathrm{mM}$ phosphate buffer solution and $10 \mu \mathrm{L}$ of $\alpha$-glucosidase ( $3 \mathrm{U} / \mathrm{mL}$ ) were pre-incubated in 96 plates at $25{ }^{\circ} \mathrm{C}$ for $5 \mathrm{~min}$. Then, $50 \mu \mathrm{L}$ of the substrate was added and the reaction mixture was incubated for $15 \mathrm{~min}$ at $25{ }^{\circ} \mathrm{C}$. 50 $\mu \mathrm{L}$ of $2 \mathrm{M}$ glycine ( $\mathrm{pH} 10)$ was added and the reaction stopped. Blank samples were prepared using the same method as the experimental sample, but the enzyme and substrate solutions used in the experimental sample were replaced with $(50 \mu \mathrm{L}) 30 \mathrm{mM}$ buffer phosphate solution while glycine was replaced with $50 \mu \mathrm{L}$ distilled water. Absorption readings were taken using the EpochTM Microplate Spectrophotometer, Biotech Instrument (USA) at $405 \mathrm{~nm}$. Percentage inhibition (\%) was calculated using the following formula:

$$
\text { Inhibition }(\%)=\frac{\Delta \mathrm{A}_{\mathrm{n}}-\Delta \mathrm{A}_{\mathrm{s}}}{\Delta \mathrm{A}_{\mathrm{s}}} \times 100
$$

where $\Delta \mathrm{A}_{\mathrm{n}}$ is the difference between a negative control (with an enzyme) and blank (without an enzyme); and $\Delta \mathrm{A}_{\mathrm{s}}$ is the difference in absorption between sample (with enzyme) with blank (without enzyme).

\section{STATISTICAL ANALYSIS}

All analytical methods to determine phenolic content, antioxidant and anti-hyperglycemic activity were performed in three replications $(n=3)$. All data were analysed using Analysis of Variance (ANOVA) and Tukey's test to determine significant differences between samples. Pearson correlation tests were used to determine the correlation between phenolic content and antioxidant and anti-hyperglycemic activities between each extract. All statistical tests were performed using Minitab version 17.0 software at the significance level of $95 \%(p<0.05)$.

\section{RESULTS AND DISCUSSION}

\section{PROXIMATE COMPOSITION C. aeruginosa}

Currently, findings on nutrient composition of $C$. aeruginosa is limited to the flower and rhizome. Therefore, the composition of important nutrients found in $C$. aeruginosa leaves was determined and is shown in Table 1. The results showed that the fresh leaves of $C$. aeruginosa had the highest moisture (85.38\%) compared to other nutrient compositions. The fresh leaves also contain $6.94 \%$ carbohydrate, the second highest after moisture content. High carbohydrate content indicates the plant's ability to produce high carbon substrates during primary metabolism, thus producing other phytochemical substances during the metabolism of secondary products (Irwan \& Shahreda 2014). Meanwhile, the fresh leaves of $C$. aeruginosa were found to have $2.69 \%$ protein. The leaf parts of a plant contain many essential amino acids for the production of enzymes that function during defense mechanisms from stress and danger (Edelman $\&$ Colt 2016). In addition, this analysis also showed that C. aeruginosa leaves have a fat content of $1.55 \%$, which is the major building block of nutrition. Results showed that leaves of $C$. aeruginosa are a good source of mineral elements as they contain a high percentage of ash $(0.89 \%)$. The fiber content $(2.55 \%)$ in this plant may be influenced by the amount of cellulose present in the tissue of the plant organ. Cellulose is responsible for preserving plant-derived proteins, which play an important role in supporting leaf growth under stress (He et al. 2015). 
TABLE 1. Proximate composition (\%) for the C. aeruginosa leaf

\begin{tabular}{lc}
\hline \multicolumn{1}{l}{ Composition } & $(\%)$ \\
\hline Moisture & $85.38 \pm 0.47$ \\
Ash & $0.89 \pm 0.08$ \\
Fat & $1.55 \pm 0.29$ \\
Carbohydrate & $6.94 \pm 0.48$ \\
Protein & $2.69 \pm 0.20$ \\
Fiber & $2.55 \pm 0.32$ \\
\hline
\end{tabular}

\section{EFFECT OF DIFFERENT SOLVENT RATIOS AND DRYING METHODS ON THE RECOVERY PERCENTAGE OF C. aeruginosa LEAF EXTRACT}

Proper drying is required to obtain optimal extraction yield, while at the same time, minimizing changes to maintain the functional properties of the extract. Percentage recovery for FD was significantly higher $(\mathrm{p}<$ 0.05 ) than OD at all solvent concentrations (Table 2). This finding is consistent with those reported by Siti Zulaikha et al. (2017) on the percentage of extracts of gooseberry tree (Phyllanthus acidus) from freeze-drying using ethanol which was higher than oven drying, with $45.64 \%$ (FD) and $28.52 \%$ for OD. Freeze-drying has a higher extraction efficiency than thermal extraction due to the breakdown of cell structure by crystalline ice formed in the plant matrix (An et al. 2016). This causes degradation of the cell wall structure, causing the intracellular product to be released into the solution (Zhang et al. 2018). In addition, if heat extraction is used, organic compounds such as protein, fat, and carbohydrates are released into carbon dioxide gas and water during the combustion process (Irwan \& Shahreda 2014). Thus, this condition affects the amount of compound left in the sample, reducing the amount of extraction obtained from oven drying.

TABLE 2. Percentage recovery of C. aeruginosa leaf extract samples with different drying method and solvent ratios

\begin{tabular}{lccc}
\hline & \multicolumn{3}{c}{ Recovery (\%) } \\
\cline { 2 - 4 } Drying method & $100: 0$ & $50: 50$ & $0: 100$ \\
\hline FD (Freeze Drying) & $13.54 \pm 0.95^{\mathrm{a}}$ & $13.89 \pm 0.15^{\mathrm{a}}$ & $10.83 \pm 0.76^{\mathrm{b}}$ \\
OD (Oven Drying) & $3.68 \pm 0.81^{\mathrm{d}}$ & $8.92 \pm 0.17^{\mathrm{c}}$ & $8.51 \pm 0.42^{\mathrm{c}}$ \\
\hline
\end{tabular}

Ratios above indicated the ratio of ethanol to water. Values represent the mean \pm standard deviation $(\mathrm{n}=3){ }^{\mathrm{a}-\mathrm{d}}$ Different letters show significant differences $(\mathrm{p}<$ 0.05 ) analyzed with Tukey's test 
The percentage of the extracts recovery can also be influenced by the nature of the solvent used. The selection of appropriate types of solvents is required as each compound present in the cell structure has different chemical properties and polarity (Stramarkou et al. 2017). Based on the results, there was a significant difference $(p<0.05)$ between the percentage of extract recovery for 100:0 and 50:50 with 0:100 for FD samples. For OD samples, 50:50 and 0:100 showed higher $(\mathrm{p}<0.05)$ recovery percentage compared to 100:0 extracts. The extraction ability of the solvent depends on the solubility of the compound in the solvent itself, the kinetics of the mass transfer of the product and the interaction strength of the soluble substance or matrix although all these factors are affected by the presence of heat (Dhanani et al. 2017).

\section{TOTAL PHENOLIC CONTENT (TPC)}

Polyphenols are the largest group of phytochemicals that act as antioxidant agents in plants. The total phenolic content found in C. aeruginosa leaves using different drying methods and solvent ratios is shown in Table 3. Results indicated that FD 50:50 had a significantly higher phenolic content of $33.06 \pm 0.36 \mathrm{mg} \mathrm{GAE} / \mathrm{g}$ extract (p $<0.05)$ compared to other extracts except for FD 100:0 extract (30.88 $\pm 3.09 \mathrm{mg} \mathrm{GAE} / \mathrm{g}$ extract). The lowest TPC value $(\mathrm{p}<0.05)$ was seen in the OD 100:0 extract. The findings of this study are in line with the total value of phenolic content of turmeric (Curcuma longa), which was the highest in extracts using aqueous alcohol mixture (678.76 mg GAE/g extract in 60:40), compared to the extraction using only water (496.76 mg GAE/g extract) (Nisar et al. 2015). Overall, from this experiment, the FD technique produced extracts with the highest phenolic content compared to the OD technique especially in the 100:0 and 50:50 extracts. This indicates that the mixture of water and alcohol could provide the maximum extraction of phenolic compounds.

TABLE 3. Total phenolic content of $C$. aeruginosa leaf extract with different drying methods and solvent ratios

\begin{tabular}{lccc}
\hline \multirow{2}{*}{ Drying method } & \multicolumn{3}{c}{ Total phenolic content (mg GAE/g extract) } \\
\cline { 2 - 4 } & $100: 0$ & $50: 50$ & $0: 100$ \\
\hline FD (Freeze Drying) & $30.88 \pm 3.09^{\mathrm{ab}}$ & $33.06 \pm 0.36^{\mathrm{a}}$ & $23.65 \pm 3.31^{\mathrm{c}}$ \\
OD (Oven Drying) & $13.31 \pm 0.46^{\mathrm{d}}$ & $26.70 \pm 0.30^{\mathrm{bc}}$ & $26.13 \pm 1.80^{\mathrm{bc}}$ \\
\hline
\end{tabular}

The sample concentration used in the calculation of total phenolic content was $1000 \mu \mathrm{g} / \mathrm{mL}$. Values represent the mean \pm standard deviation (n $=3$ ) ${ }^{\text {a-d }}$ Different letters show significant differences $(p<0.05)$ analyzed with Tukey's test

A study by An et al. (2016) found that the amount of phenolic content in ginger (Zingiber officinale Roscoe) rhizome extract was the highest using the freeze-drying method compared to oven drying (13.83 $\mathrm{mg} \mathrm{GAE} / \mathrm{g}$ FD extract versus $9.69 \mathrm{mg} \mathrm{GAE} / \mathrm{g}$ OD extract). The difference in phenolic content obtained might be due to heat and dehydration factors in the oven drying process, which could potentially destroy the structure of the phenolic compounds. Increases of temperature during the extraction process causes the bioactive compounds present in the extract to decompose (Hossain et al. 2013).

\section{FREE RADICAL SCAVENGING TEST (DPPH)}

The results from the DPPH analysis were expressed as the percentage of free radical inhibitory activity. Table 4 shows the results of the capture of DPPH free radicals by $C$. aeruginosa leaf extract by different drying methods and solvent ratios. 
TABLE 4. Inhibition percentage of free radicals of C. aeruginosa leaf extract by different drying methods and solvent ratios

\begin{tabular}{lccc}
\hline \multirow{2}{*}{ Drying method / Standard } & \multicolumn{3}{c}{ DPPH (\% inhibition) } \\
\cline { 2 - 3 } & $100: 0$ & $50: 50$ & $0: 100$ \\
\hline FD & $57.35 \pm 4.29^{\mathrm{b}}$ & $71.48 \pm 8.57^{\mathrm{a}}$ & $55.18 \pm 5.67^{\mathrm{b}}$ \\
OD & $33.02 \pm 2.18^{\mathrm{c}}$ & $24.89 \pm 6.62^{\text {cd }}$ & $17.65 \pm 4.30^{\mathrm{d}}$ \\
AA & $78.23 \pm 1.06^{\mathrm{a}}$ & $80.19 \pm 0.94^{\mathrm{a}}$ & $77.44 \pm 0.70^{\mathrm{a}}$ \\
BHA & $64.36 \pm 2.24^{\mathrm{ab}}$ & $63.07 \pm 1.79^{\mathrm{ab}}$ & $64.22 \pm 0.83^{\mathrm{ab}}$
\end{tabular}

$\mathrm{FD}=$ freeze drying; $\mathrm{OD}=$ oven drying; $\mathrm{AA}=$ ascorbic acid, $\mathrm{BHA}=$ Butylated hydroxyanisole. The sample concentration used in calculating the percentage of free radicals was $2000 \mu \mathrm{g} / \mathrm{mL}$ while $40 \mu \mathrm{g} / \mathrm{mL}$ was used for positive controls (AA and BHA). Values represent the mean \pm standard deviation $\left(\mathrm{n}=3\right.$ ). ${ }^{\mathrm{a}-\mathrm{d}}$ Different letters show significant differences $(\mathrm{p}<0.05)$ analyzed by Tukey's

The results showed that the free radical scavenging activities of extracts were higher $(p<0.05)$ in FD compared to OD for all solvent ratios tested. FD 50:50 showed the highest percentage of activity among $C$. aeruginosa leaf extracts $(\mathrm{p}<0.05)$ of $71.48 \pm 8.57 \%$. However, there was no significant difference $(\mathrm{p}>0.05)$ between the percentage of free radical scavenging activities of FD 100:0 and 0:100 extracts, which was $57.35 \pm 4.29 \%$ and $55.18 \pm 5.67 \%$, respectively. This indicates that the FD sample extracted using 50:50 ethanol:water have a higher ability to trap free radicals compared to 100:0 and 0:100 extracts. These results clearly indicate that the type of solvent and the drying methods used during the freezing process affects the rate of DPPH-free radical scavenging activity. A study by Assefa and Keum (2016) showed that yuzu (grapefruit) extracted using mix of alcohol and water exhibited the highest percentage of free radical scavenging activity compared to those extracted with pure alcohol or water. Results obtained from this study also showed that pure solvents are found to be less effective in extracting antioxidative compounds compared to a mixture of solvents.

The results of this experiment also showed that all OD extracts (100:0, 50:50 and 0:100) were not able to scavenge $50 \%$ of DPPH free radical activity. In addition, heat degradation causes the structure of the bioactive component of the compound to be destroyed, reducing the amount of phenolic in the extract, and thus, reducing the rate of free radical scavenging activity (Mokrani \& Madani
2016). This may explain the low percentage of the capture activity in extracts from OD.

\section{FERRIC REDUCING ANTIOXIDANT POWER ASSAY TEST (FRAP)}

The ability of a sample extract to act as an antioxidant can also be traced through its capability to stabilize the high-energy electrons. The results of the ferric reduction power test for the solvent concentrations and different types of drying methods on $C$. aeruginosa leaf extraction are shown in Table 5. Overall, the total ferric reducing power of different drying methods and solvent concentrations in $C$. aeruginosa leaf samples showed an increase in the order of $0 \%$ OD $<100 \%$ OD $<50 \%$ OD $<0 \%$ FD $<100 \%$ $\mathrm{FD}<50 \%$ FD.

A similar trend with the TPC results can be seen in Table 5 whereby the FD samples showed higher $(\mathrm{p}<$ 0.05 ) antioxidant activity compared to OD samples for all extracts (100:0, 50: and 0:100). FD 50:50 and 100:0 extracts recorded the highest $(\mathrm{p}<0.05)$ ferric reduction power of $42.46 \pm 1.02$ and $38.24 \pm 0.77 \mathrm{mg} \mathrm{TEAC} / \mathrm{g}$ extract compared to OD 100:0 and 0:100 extracts having the lowest ferric reduction power with $8.60 \pm 2.5$ and 4.84 $\pm 2.07 \mathrm{mg}$ TEAC/g extract. For FD, 50:50 showed higher FRAP value compared to 100:0 $(\mathrm{p}>0.05)$ and $0: 100(\mathrm{p}<$ $0.05)$. The same trend was obtained from $\mathrm{OD}$, where 50:50 extract showed significantly higher antioxidant capacity compared to both100:0 and 0:100 extracts. 
Higher ferric reduction power indicates higher antioxidant capacity to counteract the oxidation process. C. aeruginosa leaf extraction using freeze drying and a 50:50 solvent concentration has the highest potential compared to other extracts to act against the oxidation process. A report by $\mathrm{Ngo}$ et al. (2017) found that $S$. chinensis (berry magnolia) root extract obtained with water and alcohol mixtures also had the highest reducing power compared to pure water and alcohol, with higher order values such as water $<$ methanol $<$ ethanol $<50 \%$ methanol $<50 \%$ ethanol.

According to Sun et al. (2015), the type and concentration of solvent used strongly influence the number of phenolic compounds that can be extracted, thus, directly affecting the antioxidant activity in the sample. There are several other factors that influence the ability of antioxidant activity in an extract, including the preparation process such as cutting, slicing, and grinding (Sathishkumar et al. 2009), temperature, storage time, light and moisture (Zou et al. 2016), and extraction methods such as types of maceration, types and concentrations of solvent as well as the types of drying method used (Azwanida 2015). Therefore, it is important to know the type of drying and the appropriate concentration of solvent to be used during the extraction process, so that optimal results on the amount and activity of antioxidants in the extract can be obtained.

TABLE 5. Ferric reduction power of $C$. aeruginosa leaf extract with different drying methods and solvent ratios

\begin{tabular}{|c|c|c|c|}
\hline \multirow{2}{*}{ Drying method } & \multicolumn{3}{|c|}{ Ferric reducing power (mg TEAC/g extract) } \\
\hline & 100:0 & $50: 50$ & $0: 100$ \\
\hline FD (Freeze Drying) & $38.24 \pm 0.77^{\mathrm{a}}$ & $42.46 \pm 1.02^{\mathrm{a}}$ & $29.39 \pm 2.08^{b}$ \\
\hline OD (Oven Drying) & $8.60 \pm 2.53^{\mathrm{d}}$ & $14.76 \pm 1.76^{\mathrm{c}}$ & $4.84 \pm 1.59^{\mathrm{d}}$ \\
\hline
\end{tabular}

The sample concentration used in the calculation of FRAP was $1000 \mu \mathrm{g} / \mathrm{mL}$. Values represent the mean \pm standard deviation $(\mathrm{n}=3)$. ${ }^{\text {a-d }}$ Different letters show significant differences $(\mathrm{p}<0.05)$ analyzed with Tukey's test

\section{$\alpha$-GLUCOSIDASE INHIBITION TEST}

The potential of $C$. aeruginosa leaves as one of the ingredients to inhibit $\alpha$-glucosidase activity and indirectly prevent diabetes is tested using the $\alpha$-glucosidase inhibition test. The percentage of $\alpha$-glucosidase inhibition for the leaf extract of $C$. aeruginosa is shown in Table 6. The results showed that the leaf extract of $C$. aeruginosa dried using the FD method possessed a higher percentage of $\alpha$-glucosidase inhibition activity, $30.78 \pm 2.88 \%$ (FD 50:50), followed by $0: 100$ and 100:0 of $27.65 \pm 2.46 \%$ and $25.65 \pm 3.63 \%$, respectively, compared to the OD method. The lowest inhibition percentage was detected in the $0: 100$ OD extract $(10.32 \pm 1.38 \%)$. Significant differences $(p<0.05)$ can only be seen between drying types, where freeze drying (FD) showed a higher percentage of $\alpha$-glucosidase inhibition activity compared to oven drying (OD).

However, a study conducted by Sajak et al. (2016) found that extract of Ipomoea aquatica (spinach) using $100 \%$ ethanol had a higher $\alpha$-glucosidase inhibition than ethanol and water mixture. These discrepancies may be due to the structural properties of the metabolite compounds present in the extract, whether they have high polarity to organic or aqueous solutions. Furthermore, among other factors affecting the rate of $\alpha$-glucosidase inhibition activity includes the type of solvent used, the nature of the plant itself, the temperature during extraction process and the amount of original metabolites that capable of inhibiting the process of glucose decomposition (Murugesu et al. 2019). 
TABLE 6. Percentage of $\alpha$-glucosidase inhibition of $C$. aeruginosa leaf extract by different drying methods and solvent ratios

\begin{tabular}{lccc}
\hline \multirow{2}{*}{ Drying method / Standard } & \multicolumn{3}{c}{$\alpha$-glucosidase inhibition (\%) } \\
\cline { 2 - 3 } & $100: 0$ & $50: 0$ & $0: 100$ \\
\hline FD (Freeze Drying) & $25.65 \pm 3.63^{\mathrm{b}}$ & $30.78 \pm 2.88^{\mathrm{b}}$ & $27.65 \pm 2.46^{\mathrm{b}}$ \\
OD (Oven Drying) & $16.17 \pm 1.8^{\mathrm{cd}}$ & $18.01 \pm 0.54^{\mathrm{c}}$ & $10.32 \pm 1.38^{\mathrm{d}}$ \\
Quercetin & $66.00 \pm 2.03^{\mathrm{a}}$ & $63.51 \pm 1.81^{\mathrm{a}}$ & $64.89 \pm 0.86^{\mathrm{a}}$ \\
\hline
\end{tabular}

The sample concentration used in calculating the percentage of $\alpha$-glucosidase inhibition was $10000 \mu \mathrm{g} / \mathrm{mL}$ whereas the positive control (Quercetin) used was $125 \mu \mathrm{g} / \mathrm{mL}$. Values represent the mean \pm standard deviation $(n=3)$. ${ }^{\text {-d }}$ Different letters show significant differences $(\mathrm{p}<0.05)$ analyzed by Tukey's test

In this study, the positive control used was Quercetin. The percentage of $\alpha$-glucosidase inhibition for Quercetin was $66 \%$, which was significantly higher $(\mathrm{p}<0.05)$ compared to all C. aeruginosa leaf extracts. Quercetin is a bioflavonoid commonly used to regulate hyperglycemia activity and to aid in the process of glucose homeostasis in the blood (Riyaphan et al. 2017). However, the results showed that the $C$. aeruginosa leaves extract exhibited lower inhibitory activity compared to Quercetin. This was expected because Quercetin is an active pure compound while $C$. aeruginosa extract is a crude extract consisting of active and inactive compounds.

\section{CORRELATION BETWEEN PHENOLIC COMPOUNDS WITH ANTIOXIDANTS AND ANTI-HYPERGLYCEMIC ACTIVITIES}

The Pearson correlation test showed positive correlation between TPC with FRAP, DPPH and $\alpha$-glucosidase for $100: 0$ extracts $(\mathrm{r}=0.978, \mathrm{p}<0.001 ; 0.980, \mathrm{p}<0.001$ and $0.856, \mathrm{p}<0.05)$ and 50:50 $(\mathrm{r}=0.995, \mathrm{p}<0.001 ; 0.958, \mathrm{p}<$ 0.01 and $0.960, p<0.01)$ extracts. Higher phenolic content indicates higher antioxidant activity values as well as its ability to inhibit the $\alpha$-glucosidase enzyme. This indicates that phenolic content is a good indicator of antioxidant and anti-hyperglycemic activities. Phenolic compound such as flavonoids (i.e. kaempferol, Quercetin, morin and rutin) are well known as antioxidant and have been previously reported to possess $\alpha$-glucosidase inhibitory activity (Proença et al. 2017). Nonetheless, there are a few studies that only found a correlation between TPC and antioxidant properties but not with antidiabetic properties (Quan et al. 2019; Yao et al. 2012). The differences between those studies and this study is probably due to the phenolic compound in those plants were not the major compounds that contributed to the antidiabetic property (Quan et al. 2019).

\section{CONCLUSION}

The results showed that the overall best drying method was FD followed by OD. FD at 100:0 and 50:50 concentrations produced the highest phenolic content and antioxidant activity when measured using FRAP assay. For DPPH-free radical scavenging activity, FD 50:50 showed the highest percentage inhibition when compared to other extracts. In addition, FD 100:0, 50:50 and $0: 100$ showed the highest $\alpha$-glucosidase inhibition of $25.65,30.78$, and $27.65 \%$, respectively. This study also found that there is a very high correlation between phenolic content with antioxidant and anti-hyperglycemic activities of 100:0 and 50:50 C. aeruginosa leaf extracts. To conclude, results indicated that FD is the best method of drying while a solvent of 50:50 ethanol and water is considered as best solvent covering all bioassays measured in this study.

\section{ACKNOWLEDGEMENTS}

The authors would like to acknowledge the Faculty of Science and Technology, Universiti Kebangsaan Malaysia, for providing laboratory facilities. This research was supported by Geran Universiti Penyelidikan (GUP2017-121) from Universiti Kebangsaan Malaysia. 


\section{REFERENCES}

An, K., Zhao, D., Wang, Z., Wu, J., Xu, Y. \& Xiao, G. 2016. Comparison of different drying methods on Chinese ginger (Zingiber officinale Roscoe): Changes in volatiles, chemical profile, antioxidant properties and microstructure. Food Chemistry 197(1): 1292-1300.

Anuduang, A., Loo, Y.Y., Jomduang, S., Lim, S.J. \& Wan Mustapha, W.A. 2020. Effect of thermal processing on physico-chemical and antioxidant properties in mulberry silkworm (Bombyx mori L.) powder. Foods 9(7): 871-882.

Asif, M. 2015. Chemistry and antioxidant activity of plants containing some phenolic compounds. Chemistry International 1(1): 35-52.

Asmat, U., Khan, A. \& Khan, I. 2016. Diabetes mellitus and oxidative stress - A concise review. Saudi Pharmacentical Journal 24(5): 547-553.

Assefa, A.D. \& Keum, Y.S. 2016. Effect of extraction solvent and various drying methods on polyphenol content and antioxidant activities of yuzu (Citrus junos Sieb ex Tanaka). Journal of Food Measurement and Characterization 11(2): 576-585.

Association of Official Analytical Chemists (AOAC). 2000. Official Methods of Analysis. Washington D.C.: United States.

Azwanida, N.N. 2015. A review on the extraction methods use in medicinal plants, principle, strength and limitation. Medicinal and Aromatic Plants 4(3): 1-6.

Choudhury, D., Ghosal, M., Das, A.P. \& Mandal, P. 2013. Development of single node cutting propagation techniques and evaluation of antioxidant activity of Curcuma aeruginosa Roxburgh rhizome. International Journal of Pharmacy Pharmaceutical Science 5(2): 227-234.

Dent, M., Dragovic-Uzelac, V., Penic, M., Brncic, M., Bosiljkov, T. \& Levaj, B. 2013. The effect of extraction solvents, temperature and time on the composition and mass fraction of polyphenols in dalmatian wild sage (Salvia officinalis L.) extracts. Food Technology and Biotechnology 51(1): 84-91.

Dhanani, T., Shah, S., Gajbhiye, N.A. \& Kumar, S. 2017. Effect of extraction methods on yield, phytochemical constituents and antioxidant activity of Withania somnifera. Arabian Journal of Chemistry 10(1): 1193-1199.

Edelman, M. \& Colt, M. 2016. Nutrient value of leaf vs. seed. Frontiers in Chemistry 4: 32.

George, M. \& Britto, S.J. 2015. Phytochemical and antioxidant studies on the essential oil of the rhizome of Curcuma aeruginosa Roxb. International Research Journal of Pharmacy 6(8): 573-579.

Hashim, H., Ahmad, W.Y.W., Zubairi, S.I. \& Maskat, M.Y. 2019. Effect of $\mathrm{pH}$ on adsorption of organic acids and phenolic compounds by amberlite ira 67 resin. Jurnal Teknologi 81(1): 69-81.

He, M., Zhang, K., Tan, H., Hu, R., Su, J., Wang, J., Huang, L., Zhang, Y. \& Li, X. 2015. Nutrient levels within leaves, stems, and roots of the xeric species Reaumuria soongorica in relation to geographical, climatic, and soil conditions. Ecology and Evolution 5(7): 1494-1503.

Hossain, M.A., AL-Mijizy, Z.M., Al-Rashdi, K.K., Weli, A.M. \& Al-Riyami, Q. 2013. Effect of temperature and extraction process on antioxidant activity of various leaves crude extracts of Thymus vulgaris. Journal of Coastal Life Medicine 1(2): 130-134.

Hussain, T., Tan, B., Yin, Y., Blachier, F., Tossou, M.C.B. \& Rahu, N. 2016. Oxidative stress and inflammation: What polyphenols can do for us? Oxidative Medicine and Cellular Longevity 2016: 7432797.

Irwan, S.Z. \& Shahreda, N.J. 2014. Hibiscus rosa sinensis leaves: Analysis of proximate, antioxidant activities and inorganic compound. The Malaysian Journal of Analytical Sciences 18(2): 260-270.

Ismail, S.M., Hui, C.K., Aminuddin, A. \& Ugusman, A. 2018. Piper sarmentosum as an antioxidant: A systematic review. Sains Malaysiana 47(10): 2359-2368.

Jarikasem, S., Thubthimthed, S., Chawananoraseth, K. \& Suntorntanasat, T. 2005. Essential oils from three Curcuma species collected in Thailand. Acta Horticulturae 1(677): $37-41$.

Kumar, S. \& Pandey, A.K. 2013. Chemistry and biological activities of flavonoids: An overview. The Scientific World Journal 2013: 162750.

Ling, J.W.A., Chang, L.S., Mohd Khalid, R., Wan Mustapha, W.A., Sofian Seng, N.S., Mohd Razali, N.S., Abdul Rahman, H., Mohd Zaini, N.A. \& Lim, S.J. 2020. Sequential extraction of red button ginger (Costus woodsonii): Phytochemical screening and antioxidative activities. Journal of Food Processing and Preservation 44(10): e14776.

Mathela, C. \& Joshi, S. 2012. Antioxidant and antibacterial activities of the leaf essential oil and its constituents furanodienone and curzerenone from Lindera pulcherrima (Nees.) Benth. ex hook. f. Pharmacognosy Research 4(2): 80-84.

Medini, F., Fellah, H., Ksouri, R. \& Abdelly, C. 2014. Total phenolic, flavonoid and tannin contents and antioxidant and antimicrobial activities of organic extracts of shoots of the plant Limonium delicatulum. Journal of Taibah University for Science 8(3): 216-224.

Mirghani, M.E.S., Elnour, A.A.M., Kabbashi, N.A., Alam, M.Z., Musa, K.H. \& Abdullah, A. 2018. Determination of antioxidant activity of gum arabic: An exudation from two different locations. ScienceAsia 44: 179-186.

Moektiwardoyo, W.M., Tjitraresmi, A., Susilawati, Y., Iskandar, Y., Halimah, E. \& Zahryanti, D., 2014. The potential of dewa leaves (Gynura pseudochina (L.) DC) and temu ireng rhizomes (Curcuma aeruginosa Roxb.) as medicinal herbs for dengue fever treatment. Procedia Chemistry 13: 134-141.

Mokrani, A. \& Madani, K. 2016. Effect of solvent, time and temperature on the extraction of phenolic compounds and 
antioxidant capacity of peach (Prunus persica L.) fruit. Separation and Purification Technology 162: 68-76.

Murugesu, S., Ibrahim, Z., Ahmed, Q.U., Uzir, B.F., Yusoff, N.N.I., Perumal, V., Abas, F., Shaari, K. \& Khatib, A. 2019. Identification of $\alpha$-glucosidase inhibitors from Clinacanthus nutans leaf extract using liquid chromatographymass spectrometry-based metabolomics and proteinligand interaction with molecular docking. Journal of Pharmaceutical Analysis 9(2): 91-99.

Ngo, T.V., Scarlett, C.J., Bowyer, M.C., Ngo, P.D. \& Vuong, Q.V. 2017. Impact of different extraction solvents on bioactive compounds and antioxidant capacity from the root of Salacia chinensis L. Journal of Food Quality 2017: 9305047.

Nguyen, V., Van Vuong, Q., Bowyer, M., Van Altena, I. \& Scarlett, C. 2015. Effects of different drying methods on bioactive compound yield and antioxidant capacity of Phyllanthus amarus. Drying Technology 33(8): 1006-1017.

Nisar, T., Iqbal, M., Raza, A., Sadfar, M., Iftikhar, F. \& Waheed, M. 2015. Estimation of total phenolics and free radical scavenging of turmeric (Curcuma longa). American-Eurasian Journal of Agriculture and Environmental Science 15(7): 1272-1277.

Panche, A.N., Diwan, A.D. \& Chandra, S.R. 2016. Flavonoids: An overview. Journal of Nutritional Science 5(47): 1-15.

Phaniendra, A., Jestadi, D.B. \& Periyasamy, L. 2015. Free radicals: Properties, sources, targets, and their implication in various diseases. Indian Journal of Clinical Biochemistry 30(1): 11-26.

Pizzino, G., Irrera, N., Cucinotta, M., Pallio, G., Mannino, F., Arcoraci, V., Squadrito, F., Altavilla, D. \& Bitto, A. 2017. Oxidative stress: Harms and benefits for human health. Oxidative Medicine and Cellular Longevity 2017: 8416763.

Proença, C., Freitas, M., Ribeiro, D., Oliveira, E., Sousa, J., Tomé, S.M., Ramos, M.J., Silva, A., Fernandes, P.A. \& Fernandes, E. 2017. $\alpha$-Glucosidase inhibition by flavonoids: An in vitro and in silico structure-activity relationship study. Journal of Enzyme Inhibition and Medicinal Chemistry 32(1): 1216-1228.

Quan, N.V., Xuan, T.D., Tran, H.D., Thuy, N., Trang, L., Huong, C.T., Andriana, Y. \& Tuyen, P.T. 2019. Antioxidant, $\alpha$-amylase and $\alpha$-glucosidase inhibitory activities and potential constituents of Canarium tramdenum bark. Molecules 24(3): 605 .

Rahman, H.A., Saari, N., Abas, F., Ismail, A., Mumtaz, M.W. \& Abdul Hamid, A. 2017. Anti-obesity and antioxidant activities of selected medicinal plants and phytochemical profiling of bioactive compounds. International Journal of Food Properties 20(11): 2616-2629.

Riyaphan, J., Jhong, C.H., Tsai, M.J., Lee, D.N., Leong, M.K. \& Weng, C.F. 2017. Potent natural inhibitors of alphaglucosidase and alpha-amylase against hyperglycemia in vitro and in vivo. Preprints 2017: 030116.
Safitri, A., Batubara, I. \& Khumaida, N. 2017. Thin layer chromatography fingerprint, antioxidant, and antibacterial activities of rhizomes, stems, and leaves of Curcuma aeruginosa Roxb. Journal of Physics: Conference Series 835: 012014.

Sajak, A.A.B., Abas, F., Ismail, A. \& Khatib, A. 2016. Effect of different drying treatments and solvent ratios on phytochemical constituents of Ipomoea aquatica and correlation with $\alpha$-glukosidase inhibitory activity. International Journal of Food Properties 19(12): $2817-$ 2831.

Sathishkumar, R., Lakshmi, P.T.V. \& Annamalai, A. 2009 Effect of drying treatment on the content of antioxidants in Enicostemma littorale Blume. Research Journal of Medicinal Plants 3(3): 93-101.

Simoh, S. \& Zainal, A. 2015. Chemical profiling of Curcuma aeruginosa Roxb. rhizome using different techniques of solvent extraction. Asian Pacific Journal of Tropical Biomedicine 5(5): 412-417.

Simoh, S., Shin, S.Y., Abd Rahim, F., Ahmad, M.A. \& Zainal, A. 2018. Comparative analysis of metabolites and antioxidant potentials from different plant parts of Curcuma aeruginosa roxb. Sains Malaysiana 47(12): 3031-3041.

Sin, T.C., Syed Khalafu, S.H., Mustapha, W.A.W., Maskat, M.Y. \& Lim, S.J. 2018. Deodorisation of fucoidan and its effect towards physicochemical characteristics and antioxidation activities. Sains Malaysiana 47(7): 15011510.

Siti Zulaikha, A.G., Mediani, A., Khoo, L.W., Lee, S.Y., Leong, S.W. \& Abas, F. 2017. Effect of different drying methods and solvent ratios on biological activities of Phylanthus acidus extracts. Intenational Food Research Journal 24(1): 114-120.

Stramarkou, M., Papadaki, S., Kyriakopoulou, K. \& Krokida, M. 2017. Effect of drying and extraction conditions on the recovery of bioactive compounds from Chlorella vulgaris. Journal of Applied Phycology 29(6): 2947-2960.

Sun, C., Wu, Z., Wang, Z. \& Zhang, H. 2015. Effect of ethanol/ water solvents on phenolic profiles and antioxidant properties of Beijing propolis extracts. Evidence-Based Complementary and Alternative Medicine 2015: 595393.

Thaina, P., Tungcharoena, P., Wongnawaa, M., Reanmongkol, W. \& Subhadhirasakul, S. 2009. Uterine relaxant effects of Curcuma aeruginosa Roxb. rhizome extracts. Journal of Ethnopharmacology 121(1): 433-443.

Yao, Y., Cheng, X.Z., Wang, L.X., Wang, S.H. \& Ren, G. 2012. Major phenolic compounds, antioxidant capacity and antidiabetic potential of rice bean (Vigna umbellata L.) in China. International Journal of Molecular Sciences 13(3): 2707-2716.

Zayapor, M.N., Abdullah, A. \& Mustapha, W.A.W. 2020. Antioxidant and anti-diabetic status of popular Malay health tonic consumed for wellness: Help or hype? Sains Malaysiana 49(1): 145-154. 
Zhang, Z., Liu, Y. \& Che, L. 2018. Effects of different drying methods on the extraction rate and qualities of oils from demucilaged flaxseed. Drying Technology 36(13): $1642-$ 1652.

Zou, Z., Xi, W., Hu, Y., Nie, C. \& Zhou, Z. 2016. Antioxidant activity of citrus fruits. Food Chemistry 196(1): 885-896.

Wan Najiyah Hanun Wan Nasir, Nurul Najiha Ain Ibrahim, Woon Kuo Hao, Noor-Soffalina Sofian-Seng, Wan Aida Wan Mustapha \& Hafeedza Abdul Rahman*

Department of Food Sciences

Faculty of Science and Technology

Universiti Kebangsaan Malaysia

43600 UKM Bangi, Selangor Darul Ehsan

Malaysia
Noor-Soffalina Sofian-Seng, Wan Aida Wan Mustapha \& Hafeedza Abdul Rahman*

Innovation Centre for Confectionery Technology (MANIS)

Faculty of Science and Technology

Universiti Kebangsaan Malaysia

43600 UKM Bangi, Selangor Darul Ehsan

Malaysia

Azliana Abu Bakar Sajak

Department of Nutrition

Faculty of Medicine and Health Sciences

Universiti Putra Malaysia

43400 UPM Serdang, Selangor Darul Ehsan

Malaysia

*Corresponding author; email: hafeedzarahman@ukm.edu.my

Received: 3 March 2020

Accepted: 29 December 2020 